\title{
RELATIONSHIP OF TNF-A-308, IL-10-1082 GENE POLYMORPHISMS WITH THE SEVERITY AND SUSCEPTIBILITY OF RHEUMATIC HEART DISEASE IN TURKISH CHILDREN
}

\author{
Hallioglu Olgu ${ }^{1}$, Balci Sibel ${ }^{1}$, Eras-Erdogan Nazan ${ }^{2}$, Akbas Etem $^{2}$
}

\begin{abstract}
Aim. Acute rheumatic fever is an inflammatory disease developing after upper respiratory tract infection with group A streptoccoci and its most important complication is rheumatic heart disease (RHD). Tumor necrosis factor (TNF)- $\alpha$ and interleukin (IL) -1-1082 gene polymorphisms were associated with susceptibility to develop rheumatic heart disease. The aim of our study is to determine the frequency of IL-10-1082 A/G and TNF- $\alpha-308 \mathrm{G} / \mathrm{A}$ gene polymorphism in Turkish population and to investigate the relationship between these polymorphisms and rheumatic heart disease.

Material and Methods. Genotypes of 57 unrelated children with rheumatic heart disease and 99 controls were determined by use of PCR-RFLP.

Results. No significant differences were found in genotypes or allele frequencies of TNF- $\alpha-308$ and IL-10-1082 genes between RHD and control group. There was no relation between TNF- $\alpha$-308 genotype and allel distribution with valvular involvement ( $>$ >0.05). IL-10-1082 GG and AG genotypes were seen more frequent in patients with multiple valvular disease but there was no statistical significance $(p>0.05)$.

Conclusion. As a result, there was no relationship between TNF- $\alpha-308$, IL-10 1082 gene polymorphisms and rheumatic heart disease or valvular involvement in the study population $(p>0,05)$. Our results are thought that TNF- $\alpha-308$ polymorphisms are silent and may become important only with some certain HLA allels. Further studies checking both cytokine polymorphism and HLA allels are needed.
\end{abstract}

Russ J Cardiol 2014, 7 (111), Engl.: 42-46

Key words: polymorphism, rheumatic heart disease, IL-10-1082, TNF- $\alpha-308$.

'Department of Pediatric Cardiology, Faculty of Medicine, Mersin University, Mersin; ${ }^{2}$ Department of Medical Biology and Genetics, Faculty of Medicine, Mersin University, Mersin, Turkey.

Corresponding author. Olgu Hallioglu, MD, Mersin University Faculty of Medicine. Department of Pediatrics, Section of Pediatric Cardiology. 33079 Zeytinlibahce/Mersin, Turkey. Tel: +903243374300-1149, Fax: +903243374305, e-mail: olguhallioglu@yahoo.com

IL — interleukin, RF — rheumatic fever, RHD - rheumatic heart disease, SNP single nucleotide polymorphisms, TNF - tumor necrosis factor.

Received February 11, 2014

Revision received February 19, 2014.

Accepted February 26, 2014

\section{ОТНОШЕНИЯ ПОЛИМОРФИЗМОВ ГЕНОВ ТNF-А-308 И ИЛ-10-1082 С ТЯЖЕСТЬЮ И ВОСПРИИМЧИВОСТЬЮ К РЕВМАТИЧЕСКОЙ БОЛЕЗНИ СЕРДЦА У ТУРЕЦКИХ ДЕТЕЙ}

\author{
Hallioglu Olgu ${ }^{1}$, Balci Sibel ${ }^{1}$, Eras-Erdogan Nazan ${ }^{2}$, Akbas Etem $^{2}$
}

Цель. Острая ревматическая лихорадка - это воспалительное заболевание, которое развивается после инфицирования верхних дыхательных путей группой стрептококка А и его важнейшими осложнениями являются ревматические пороки сердца (РПС). Фактор некроза опухоли (TNF) - $\alpha$ и интерлейкин (IL) -1-1082 полиморфизмы генов были связаны со склонностью к развитию ревматической болезни сердца. Целью нашего исследования является определение частоты генного полиморфизма IL-10-1082 A/G и TNF- $\alpha-308$ G/A у турецкого населения, и исследование отношений между этими полиморфиз мами и ревматической болезнью сердца.

Материал и методы. Генотипы 57 неродственных детей с ревматическими пороками сердца и 99 детей (группа контроля) были определены с использованием ПЦР-ПДРФ.

Результаты. Не обнаружено значимых различий в генотипах или частоте аллеля TNF- $\alpha-308$ и IL-10-1082 генов между PПС и контрольной группой. Не было никакой связи между генотипом TNF- $\alpha-308$ и аллелью распределение с вовлечением клапанов (p>0,05).Генотипы IL-10-1082 GG и AG наблюдались

\section{Introduction}

Rheumatic heart disease (RHD) is an inflammatory disorder and autoimmune sequel of group A streptococcal infection complicated by rheumatic fever (RF). Autoimmunity induced by antigenic mimicry between the streptococcal glycoprotein and human cardiac miyosin may be responsible for the pathogenesis of RHD [1]. High familial incidence of RF suggests that genetic factors play a role in susceptibility to RF and RHD. RF is still public health burden in Turkey as in developing countries [2].

Cytokines appear to play a critical role in triggering inflammatory and immunologic reactions in RF. Increase чаще у больных с множественными клапанными пороками, но не было никакой статистической значимости ( $p>0,05)$.

Заключение. Как следствие, не существует никакой связи между полиморфизмами генов TNF- $\alpha-308$, IL-10-1082 и ревматической болезнью сердца или вовлечения клапанов в исследуемой популяции $(p>0,05)$. Наши результаты предполагают, что полиморфизмы TNF- $\alpha$-308 неактивны и могут стать актуальными только при некоторых определенных аллелях HLA. В дальнейших исследованиях необходима проверка обоих цитокинов и полиморфизма аллелей HLA.

Российский кардиологический журнал 2014, 7 (111), Англ.: 42-46

Ключевые слова: полиморфизм, ревмокардит, IL-10-1082, TNF- $\alpha-308$.

'Department of Pediatric Cardiology, Faculty of Medicine, Mersin University, Mepсин; ${ }^{2}$ Department of Medical Biology and Genetics, Faculty of Medicine, Mersin University, Мерсин, Турция.

in tumor necrosis factor (TNF) - $\alpha$ and interleukin (IL) -1 levels in patients with RF and RHD have been known for a long time [3]. Even, that IL-1 $\alpha$ in carditis and IL-6 in arthritis may be helpful as minor criteria for diagnosis of RF has been considered [4]. IL-10 is another important immunoregulatory cytokine. The biological actions are mainly inhibitory including inhibition of pro-inflammatory cytokines [5].

Single nucleotide polymorphisms (SNPs) in regulatory regions of cytokine genes can lead to the susceptibility and onset of diseases. The human TNF- $\alpha$ gene is located in the HLA region of human chromosome 6 and contains several 
polymorphic sites. TNF- $\alpha$ biallelic SNPs at position $-238,-308$, and -376 with respect to the TNF transcriptional start site are all substitutions of adenine (A) for guanine $(G)[6]$. Several SNPs in the promoter region of IL-10 have been described but one of the the most investigated are located at positions -1082 of the transcriptional start site [5]. In RHD, a relationship between TNF- $\alpha-308$, and IL-10-1082 polimorphisms and multivalvar involvement has been determined [4]. Since cytokine gene polymorphisms are specific on the basis of population, there are very few studies about TNF$\alpha-308$ and IL-10-1082 gene polymorphism in Turkish children with RF of which results have also been conflicting. The aim of our study is to find out the possible influences of IL-10-1082 A/G and TNF- $\alpha-308$ G/A gene polymorphisms on RHD development. Besides; on the basis of our sample, to determine the allel and genotype frequencies of IL-10-1082 A/G and TNF- $\alpha-308 \mathrm{G} / \mathrm{A}$ polymorphisms in Turkish population are also aimed.

\section{Material and Methods}

\section{Patients}

This study included 57 unrelated children with RHD recruited from the pediatric cardiology department at the Mersin University Medical Faculty. Patients were diagnosed according to Jones' modified criteria and the lesions of RHD were confirmed by echocardiography. The control group consisted of 99 healthy unrelated children diagnosed with innocent murmur who had normal echocardiography. The genotyping success rate was $97.8 \%$ for the TNF- $\alpha-308$ polymorphism and $88.0 \%$ for the IL-10-1082 polymorphism. Demographic characteristics, personal or family history of rheumatic fever, and echocardiographic results were obtained from the groups. The exclusion criteria for control group consisted of subjects who have history of rheumatic fever or related persons. Besides, the subjects with the history of other autoimmune associated diseases were excluded. This study had received Ethical Approval from the Mersin University Medical Faculty Ethics Committee and inform consents were given.

\section{Genotype Analyses}

Genomic DNA was extracted by the standard phenolchloroform methods from peripheral blood leukocytes. The polymorphisms were analyzed by using of PCR/ RFLP. The primary sequences for the TNF- $\alpha-308$ forward and reverse primaries were (5'-AGGCAATAGGTTTTGAGGGCCAT-3') and (5'-TCCTCCCTGCTCCGATTCCG-3'), respectively. In order to characterize the IL-10-1082 polymorphism, forward (5'-CTCGCTGCAACCCAACTGGC-3') and reverse (5'-TCTTACGCAACCCAACTGGC-3') primaries were used. PCR amplification was performed in a final volume of $23 \mu \mathrm{l}$ containing $30 \mathrm{ng}$ genomic DNA, 50 pmol of each TNF- $\alpha-308$ and IL-10-1082 primaries, 0.2
$\mathrm{mM}$ dNTPs, 1XPCR buffer with $\left(\mathrm{NH}_{4}\right){ }_{2} \mathrm{SO}_{4}, 2.5 \mathrm{mM}$ $\mathrm{MgCl}_{2}, 10 \% \mathrm{DMSO}$, and $2.0 \mathrm{U}$ of Taq DNA polymerase (Sigma-D4545).

The PCR conditions for the TNF- $\alpha-308$ gene were initial denaturation at $96{ }^{\circ} \mathrm{C}$ for $2 \mathrm{~min}, 35$ cycles of denaturation for $45 \mathrm{~s}$ at $96{ }^{\circ} \mathrm{C}$, annealing for $1 \mathrm{~min}$ at $60{ }^{\circ} \mathrm{C}$, and extension for $90 \mathrm{~s}$ at $72{ }^{\circ} \mathrm{C}$, terminated by a 7 min elongation at $72{ }^{\circ} \mathrm{C}$. The $107 \mathrm{bp}$ PCR product was digested with $N c o$ I restriction endonuclease (MBI, Fermentas, Vilnius, Lithuania) for overnight at $37^{\circ} \mathrm{C}$. The PCR conditions for the IL-10-1082 gene were initial denaturation at $95{ }^{\circ} \mathrm{C}$ for $5 \mathrm{~min}, 35$ cycles of denaturation for $30 \mathrm{~s}$ at $95^{\circ} \mathrm{C}$, annealing for $45 \mathrm{~s}$ at $60{ }^{\circ} \mathrm{C}$, and extension for $30 \mathrm{~s}$ at $72{ }^{\circ} \mathrm{C}$, terminated by a $7 \mathrm{~min}$ elongation at $72{ }^{\circ} \mathrm{C}$. The $139 \mathrm{bp}$ PCR product was digested with $M n I I$ restriction endonuclease (MBI, Fermentas, Vilnius, Lithuania) for overnight at $37{ }^{\circ} \mathrm{C}$. The digestion products were electrophoretically separated on a $3 \%$ agarose gel and visualized using ethidium bromide staining.

\section{Statistical analysis}

Continuous variables were presented as mean \pm standard deviation and categorical variables as numbers and percentages. The "independent sample t-test" was used for comparison of continuous variables between case group and control group. The distribution of genotype and allele frequencies between cases and controls was compared using the "chi-square test".

We calculated odds ratios and $95 \%$ confidence intervals using logistic regression. The allele and genotype frequencies are in "Hardy-Weinberg equilibrium". Statistical analyses were performed by use of the computer software SPSS for Windows, version 11.5 and the value of $p<0.05$ was considered statistically significant.

\section{Clinical characteristics}

Our study population consisted of 57 RHD patients (27 female, 30 male) and 99 age-matched healthy control subjects (43 female, 56 male) without a history of heart failure. The mean age of the patients was $12,2 \pm 2,5$ years (range, 7-18 years) and the mean age of the control group was $12,0 \pm 2,7$ years (range, $7-17$ years).

Demographical characteristics of the patients and controls are shown in Table 1. There were no significant differences in age, gender and socio-economic status, between the patients and controls. It is remarkable that positive family history of RHD was present in $19 \%$ of cases. Depending on the exclusion criteria, no family history has been reported in the control group. Carditis were only major manifestation of the disease in most of the patients. While 21 patients had arthritis and 3 patients had Sydenham's chorea as well as carditis. On the basis of valvular involvement, $16(28,1 \%)$ patients had mitral regurgitation, $10(17,5 \%)$ had aortic 
Table 1

Demographical characteristics of patients and controls

\begin{tabular}{|l|l|l|l|}
\hline & $\begin{array}{l}\text { Patients } \\
(\mathrm{n}=57)\end{array}$ & $\begin{array}{l}\text { Controls } \\
(\mathrm{n}=99)\end{array}$ \\
\hline Age (year) & $12,19 \pm 2,51$ & $12,01 \pm 2,66$ \\
\hline Gender (F/M) (\%) & $27(47,4) / 30(52,6)$ & $43(43,4) / 56(56,6)$ \\
\hline Parental consanguinity (\%) & $15(26,3)$ & $30(30,3)$ & 0,625 \\
\hline Family history of RF & $19(33,3)$ & - & 0,738 \\
\hline Low socioeconomical status & $28(49,1)$ & $40(40,4)$ & - \\
\hline
\end{tabular}

Abbreviations: $\mathrm{F}$ - female, $\mathrm{M}-$ male, $\mathrm{RF}$ - rheumatic fever.

Table 2

Allele and genotype frequencies of TNF- $\alpha-308$ and IL-10-1082 in patients and controls

\begin{tabular}{|c|c|c|c|c|c|}
\hline & Patients & Controls & $\mathrm{P}$ & OR & $95 \% \mathrm{Cl}$ \\
\hline TNF- $\alpha-308$ & $(n=57)$ & $(n=97)$ & & & \\
\hline \multicolumn{6}{|l|}{ Genotypes } \\
\hline GG (\%) & $45(78,9)$ & $64(66)$ & & 1,0 (ref) & \\
\hline$A G(\%)$ & $12(21,1)$ & $30(30,9)$ & NS & 0,569 & $0,263-1,230$ \\
\hline $\mathrm{AA}(\%)$ & 0 & $3(3,1)$ & NS & 0,202 & $0,010-4,017$ \\
\hline \multicolumn{6}{|l|}{ Alleles } \\
\hline $\mathrm{G}(\%)$ & $102(89,5)$ & $158(81,4)$ & NS & 1,937 & $0,963-3,897$ \\
\hline$A(\%)$ & $12(10,5)$ & $36(18,6)$ & NS & 0,516 & $0,257-1,039$ \\
\hline IL-10-1082 & $(n=54)$ & $(n=82)$ & & & \\
\hline \multicolumn{6}{|l|}{ Genotypes } \\
\hline $\mathrm{AA}(\%)$ & $28(51,9)$ & $33(40,2)$ & & 1,0 (ref) & \\
\hline AG (\%) & $21(38,9)$ & $40(48,8)$ & NS & 0,618 & $0,298-1,283$ \\
\hline GG (\%) & $5(9,3)$ & $9(11)$ & NS & 0,654 & $0,196-2,180$ \\
\hline$A(\%)$ & $77(71,3)$ & $106(64,6)$ & NS & 1,359 & $0,803-2,299$ \\
\hline $\mathrm{G}(\%)$ & $31(28,7)$ & $58(35,4)$ & NS & 0,736 & $0,435-1,245$ \\
\hline
\end{tabular}

Abbreviations: OR - odds ratio, $95 \% \mathrm{Cl}-95 \%$ confidence intervals, NS - not significant.

regurgitation and $31(54,4 \%)$ had both aortic and mitral regurgitation.

\section{TNF- $\alpha$ polymorphism analysis}

The genotypic and allelic distributions of TNF- $\alpha-308$ and IL-10-1082 polymorphisms for cases and controls are shown in Table 2. The frequencies of $\mathrm{G}$ and $\mathrm{A}$ alleles for the TNF- $\alpha-308$ gene were $89,5 \%$ and $10,5 \%$ in the cases and $81,4 \%$ and $18,6 \%$ in the controls, respectively. These differences were not significant. Among the cases, the prevalence of the GG, AG and AA genotypes were $78.9 \%$, $21,1 \%$ and $0 \%$, while it was $66 \%, 30,9 \%$ and $3,1 \%$ among the controls, respectively. The homozygous AA genotype was not observed in cases our study. Significance of the deviation of observed genotype frequencies from those predicted by the Hardy-Weinberg law was determined using $\chi^{2}$ analysis in both groups $(\mathrm{p}=0,001)$. No considerable differences were observed in allele or genotype frequencies for the IL-10-1082 gene between RHD and controls. The frequencies of $\mathrm{A}$ and $\mathrm{G}$ alleles for the IL-10-1082 gene were $71,3 \%$ and $28,7 \%$ in the cases whereas $64,6 \%$ and $35,4 \%$ in the controls, respectively.
The frequencies of the AA, AG, and GG genotypes in the control and case groups were $51,9 \%, 38,9 \%$, and 9,3\%, and $40,2 \%, 48,8 \%$, and $11 \%$, respectively. The genotype distributions were in accordance with the Hardy-Weinberg equlibrium among patient group and control group $(p=3,15$ and $\mathrm{p}=0,58$, respectively).

We also analyzed relation between genotype and allel distribution of TNF- $\alpha-308$ and IL-10-1082 gene polymorphism with valvular involvement (Table 3 ). However, there was no relation between TNF- $\alpha-308$ genotype and allel distribution with valvular involvement ( $>0,05)$. IL-10-1082 GG and AG genotypes were observed more frequently in patients with multiple valvular disease but there was no statistical significance $(p>0,05)$.

\section{Discussion}

In many autoimmune diseases, the role of TNF- $\alpha$ and IL-10 was investigated [7, 8]. In general, the effect of TNF- $\alpha$ is pro-inflammatory, IL-10 is immunosuppressive and anti-inflammatory. Especially, TNF- $\alpha$ has an active role in the pathogenesis of rheumatic diseases. Besides, in 


\section{Allele and genotype frequencies of TNF- $\alpha-308$ and IL-10-1082 in patients with different valve damage}

\begin{tabular}{|c|c|c|c|c|c|}
\hline & SVL & MVL & $\mathrm{P}$ & OR & $95 \% \mathrm{Cl}$ \\
\hline TNF- $\alpha-308$ & $(n=26)$ & $(n=31)$ & & & \\
\hline \multicolumn{6}{|l|}{ Genotypes } \\
\hline GG (\%) & $21(80,8)$ & $24(77,4)$ & NS & 0,816 & $0,225 \pm 2,961$ \\
\hline AG (\%) & $5(19,2)$ & $7(22,6)$ & NS & 1,225 & $0,338 \pm 4,443$ \\
\hline AA (\%) & 0 & 0 & & & \\
\hline \multicolumn{6}{|l|}{ Alleles } \\
\hline$A(\%)$ & $5(9,6)$ & $7(11,3)$ & & 1,196 & $0,356 \pm 4,019$ \\
\hline G (\%) & $47(90,4)$ & $55(88,7)$ & & 0,836 & $0,249 \pm 2,808$ \\
\hline IL-10-1082 & $(n=25)$ & $(n=29)$ & & & \\
\hline \multicolumn{6}{|l|}{ Genotypes } \\
\hline AA (\%) & $15(60)$ & $13(44,8)$ & & 1,0 (ref) & \\
\hline AG (\%) & $9(36)$ & $12(41,4)$ & NS & 1,538 & $0,492 \pm 4,808$ \\
\hline GG (\%) & $1(4)$ & $4(13,8)$ & NS & 4,610 & $0,456 \pm 46,673$ \\
\hline \multicolumn{6}{|l|}{ Alleles } \\
\hline $\mathrm{A}(\%)$ & $39(78)$ & $38(65,5)$ & NS & 0,536 & $0,227 \pm 1,267$ \\
\hline $\mathrm{G}(\%)$ & $11(22)$ & $20(34,5)$ & NS & 1,866 & $0,789 \pm 4,413$ \\
\hline
\end{tabular}

Abbreviations: OR - odds ratio, $95 \% \mathrm{Cl}-95 \%$ confidence intervals, SVL - single valvular lesions (mitral or aortic), MVL - multivalvular lesions, NS - not significant.

the cases of inflammatory involvements of the heart, the level of TNF- $\alpha$ has been increased [3]. It has also been demonstrated that TNF- $\alpha-308$ polymorphism is associated with high TNF- $\alpha$ production [9]. Due to the fact that, several studies have been conducted to evaluate the association of the TNF- $\alpha-308$ gene polymorphism and RHD. The results, however, are conflicting. One study has showed that A allele $(\mathrm{OR}=10,8)$ and $\mathrm{AG}$ genotype $(\mathrm{OR}=9,85)$ have been associated with RHD [10]; on the other hand, borderline association between RHD and TNF- $\alpha-308$ gene polymorphism $(\mathrm{OR}=1,4)$ has been reported [11]. In addition, this study showed that TNF- $\alpha-$ 308 polymorphism was related to the development of mitral valve lesions in a cohort of Brazilian RHD patients $(\mathrm{OR}=1,9)$ [11]. Furthermore, Settin et al. [4] demonstrated that all RHD cases had a significantly higher frequency of AA genotype of TNF- $\alpha-308$ gene polymorphism $(\mathrm{OR}=5,7)$. Recently, Rehman et al. [12] observed that the TNF- $\alpha-308$ AA and GA genotypes were associated with susceptibility to RHD (OR=9,94 and $\mathrm{OR}=1,97$, respectively). There is only one study in the Turkish population where an association of TNF- $\alpha-308$ A allele with RHD has been observed $(\mathrm{OR}=3,3)$ [13]. On the other hand, in two studies from Turkey no differences in the distribution of genotypes between cases and controls were observed [14, 15], and these results were similar to those of our study.

In the literature, there are only three studies on the association of IL-10-1082 gene polymorphism with RHD of which results were controversial. Settin et al. [4] found that the frequency of AA and GG genotypes was higher in RHD than controls, which supported a role for the IL-10-1082 polymorphism in determining the risk of
RHD. Rehman et al. [12] reported that no association was found between IL-10-1082 polymorphism and susceptibility to RHD. Another study from Turkey reported no association between IL-10-1082 genotype and RHD, which are similar to our results [15].

Previous studies examined associations between TNF- $\alpha-308$ and IL-10-1082 polymorphisms with valvular involvement. We did not find an association between the TNF- $\alpha-308$ and IL-10-1082 polymorphisms and valvular involvement in the Turkish population. An association between TNF- $\alpha-308$ polymorphism and patients with multivalvar disease in a Mexican population has been reported. The TNF- $\alpha-$ 308 AG genotype and A allele frequencies were increased in patients with multivalvar disease when compared controls $(\mathrm{OR}=14$ and $\mathrm{OR}=11,7$, respectively $)$. There was also increased frequency of TNF- $\alpha-308 \mathrm{~A}$ allele in patients with multivalvar lesion $(\mathrm{OR}=8.65)$ [10]. Settin et al. [4], reported that valvular involvement is associated with TNF- $\alpha-308$ and IL-10-1082 polymorphisms in the Egypt population. They found that increased frequencies of genotypes TNF- $\alpha-308$ AA, GG with IL-10-1082 GG in cases with multivalvular disease. Also genotypes AA of both TNF- $\alpha-308$ and IL-101082 were increased in patients with multivalvular lesions.

\section{Conclusion}

In this study, which was conducted in a Mersin sample, the results have demonstrated that IL-10-1082 A/G and TNF- $\alpha-308$ G/A gene polymorphisms had no influence on the risk of RHD development. Besides, no relationship between TNF- $\alpha-308$ and IL-10-1082 gene polymorphisms 
with RHD and valvular involvement was detected. The rates of allel and genotypes of control group contribute to determine the frequencies of these polymorphisms in Turkish population.

\section{References}

1. Zabriskie JB. Rheumatic fever: a model for the pathological consequences of microbialhost mimicry. Clin Exp Rheumatol 1986;4:65-73.

2. Ozer S, Hallioğlu O, Ozkutlu S, et al. Childhood acute rheumatic fever in Ankara, Turkey. Turk J Pediatr 2005;47:120-4.

3. Miller LC, Gray ED, Mansour M, et al. Cytokines and immunoglobulin in rheumatic heart disease: production by blood and tonsillar mononuclear cells. J Rheumatol 1989; $16: 1436-42$

4. Settin A, Abdel-Hady H, El-Baz R, et al. Gene polymorphisms of TNF-alpha (-308), IL-10 (-1082), IL-6 (-174), and IL-1Ra (VNTR) related to susceptibility and severity of rheumatic heart disease. Pediatr Cardiol 2007;28:363-71.

5. Henderson C, Goldbach-Mansky R. Monogenic autoinflammatory diseases: new insights into clinical aspects and pathogenesis. Curr Opin Rheumatol 2010;22:567-78.

6. Knight JC, Udalova I, Hill AV, et al. A polymorphism that affects OCT-1 binding to the TNF promoter region is associated with severe malaria. Nature Genet 1999;22:145-50.

7. Ates $\mathrm{O}$, Hatemi $\mathrm{G}$, Hamuryudan V, et al. Tumor necrosis factor-alpha and interleukin-10 gene promoter polymorphisms in Turkish rheumatoid arthritis patients. Clin Rheumato 2008;27:1243-8.

8. Pawlik A, Kurzawski M, Szklarz BG, et al. Interleukin-10 promoter polymorphism in patient with rheumatoid arthritis. Clin Rheumatol 2005;24:480-4

9. Bouma G, Crusius JB, Oudkerk Pool M, et al. Secretion of tumour necrosis factor alpha

\section{Acknowledgement}

The present study was supported by the Project of Scientific Research of Mersin University.

and lymphotoxin alpha in relation to polymorphisms in the TNF genes and HLA-DR alleles. Relevance for inflammatory bowel disease. Scand J Immunol 1996;43:456-63.

10. Hernández-Pacheco G, Flores-Domínguez C, Rodríguez-Pérez JM, et al. Tumor necrosis factor-alpha promoter polymorphisms in Mexican patients with rheumatic heart disease. J Autoimmun 2003;21:59-63.

11. Ramasawmy R, Faé KC, Spina G, et al. Association of polymorphisms within the promoter region of the tumor necrosis factor-alpha with clinical outcomes of rheumatic fever. Mol Immunol 2007;44:1873-8.

12. Rehman S, Akhtar N, Saba N, et al. A study on the association of TNF- $\alpha(-308)$, IL-6 (-174), IL-10 (-1082) and IL-1Ra (VNTR) gene polymorphisms with rheumatic heart disease in Pakistani patients. Cytokine 2013;61:527-31.

13. Sallakci N, Akcurin G, Köksoy S, et al. TNF-alpha G-308A polymorphism is associated with rheumatic fever and correlates with increased TNF-alpha production. J Autoimmun 2005;25:150-4.

14. Berdeli A, TabelY, Celik HA, et al. Lack of association between TNF- $\alpha$ gene polymorphism at position -308 and risk of acute rheumatic fever in Turkish patients. Scand J Rheumatol 2006;35:44-7.

15. Col-Araz N, Pehlivan S, Baspinar O, et al. Role of cytokine gene (IFN- $\gamma$, TNF- $\alpha$, TGF- $\beta 1$, IL-6, and IL-10) polymorphisms in pathogenesis of acute rheumatic fever in Turkish children. Eur J Pediatr 2012;171:1103-8. 